\title{
Effect of Strategic Orientation on Performance of Star-Rated Hotels in Ghana
}

\author{
${ }^{1}$ Dominic Owusu, ${ }^{2}$ Ishmael Mensah, ${ }^{3}$ Edem K. Amenumey \& \\ ${ }^{4}$ Rebecca Dei Mensah \\ ${ }^{1}$ Department of Marketing and Supply Chain Management \\ University of Cape Coast \\ Email: dowusu@ucc.edu.gh \\ ${ }^{2,3}$ Department of Tourism and Hospitality Management \\ University of Cape Coast \\ Email: ikmensah@ucc.edu.gh $h^{2}$ : eamenumey@ucc.edu.gh \\ ${ }^{4}$ Department of Human Resource Management \\ University of Cape Coast \\ Email: rdeimensah@ucc.edu.gh
}

\begin{abstract}
The study used the resource dependency theory to determine the strategic orientation that starrated hotels in Ghana should adopt to realize both financial and non-financial performance. Out of a population of 680 hotel managers, a sample of 248 were chosen, using the stratified random sampling technique. Self-administered questionnaires were used to solicit the views of managers of the selected starrated hotels. In all, a total of 178 responses were retrieved and analyzed, using descriptive and partial least squares in structural equation modeling. Findings of the study indicate that none of the strategic orientation types influenced financial performance.
\end{abstract}

aggressiveness, analytic, defensiveness, futuristic and riskiness were found to rather influence non-financial performance of star-rated hotels. The study, therefore, confirms the resource dependency theory and concludes that when starrated hotels tend to be aggressive, analytic, futuristic and risky, it influences nonfinancial performance. The study, therefore, recommends that managers of star-rated hotels use analytic, defensiveness, futuristic and riskiness strategic orientation to enhance nonfinancial performance.

Keywords: Strategic orientation, performance, star-rated hotels, financial performance, nonfinancial performance 


\section{Introduction}

A key determinant of business success, as described in the study of Deshpande and Webster (1989), is strategic orientation. Han and Verma (2012) explained that a firm's strategic orientation is a set of behaviours that operationalize its overarching strategy. Lynch, Mason, Beresford and Found (2012) also are of the view that strategic orientation defines how an organisation pursues its business. This orientation, according to the authors, guides the corporate strategy and provides the guiding philosophy of the firm. Avci, Madnoglu and Okumus (2010) explained strategic orientation as the way a firm adapts to its external environment. Further, strategic orientation focuses on how a firm should interact with external environmental aspects such as customers, competitors and technology.

Strategic orientation of a firm has also been linked to superior performance of firms (Nzioka \& Njuguna, 2017, Obeidat et al. 2016, Han \& Verma, 2012, Heiens \& Pleshko,
2011). According to Zhou and Li (2010), strategic orientation drives superior performance. Similarly, a recent study by Nzioka and Njuguna (2017) in Narobi also found out that strategic orientation had a positive and significant effect on hotels in Nairobi County. It can, therefore, be inferred that the strategic orientation of a firm is likely to influence how a firm interacts with its external environment and it can also influence the success or failure of the firm.

As the hotel sector of Ghana continues to record increases in the number of starrated hotels, such as Kempinski, Movenpick Ambassador, Tang Palace, and Atlantic hotel, competition in the sector has been fierce as more strategies are being deployed to court attraction and occupancy to their respective facilities. The hotels in Ghana should be able to identify the strategic orientation that must be pursued in order to record increases in their performances. A review of literature indicates lack of studies in the hotel sector, 
especially in Ghana. Most of the literature reviewed were studies conducted outside Ghana and most of these studies were also conducted in industries outside of the hospitality industry. Ghana being one of the emerging economies in the West African sub-region, with a stable economy, and growing hotel sector, requires such studies to be able to provide an understanding of how actors in the sector should interact with their external environment to sustain their businesses.

A study to determine the effect of strategic orientation on the performance of hotels, therefore, becomes imperative. Despite the link between strategic orientation and performance, little research has focused directly on how hotels can maximize performance through the development of a strategic action plan (Han \& Verma 2012) that provides direction on how hotels should interact with external environment. Studies to determine the strategic orientation that hotels should adopt in order to record increases in performance has been lacking in Ghana. In this regard, the current study sought to determine the effects of strategic orientation types on both financial and non-financial performance of star-rated hotels in Ghana. Findings of the study, therefore, contribute to the debate on the effect of strategic orientation on the performance of hotels and provide hotel managers in Ghana the strategic orientation type to adopt in order to achieve a certain level of organisational performance.

\section{Literature Review}

The theory that underpins the study is the theory of resource dependency. The theory explains how a firm interacts with its external environment and how such an interaction influences the ability of the firm to achieve its performance targets. The strategic orientation that the firm adopts is to help the firm to interact with the external environment. The strategic orientation provides direction on how a firm interacts with the external environment. This is explained by the type of strategic 
orientation that a firm adopts in interacting with the elements of its environment. The theory argues that the long-term survival and success of a firm are dependent on its abilities to link the firm with its external and internal environment (Pfeffera \& Salancik, 1978). A basic argument in the theory is that firms constantly must interact with their environment. Therefore, firms should concentrate on how to control the external environment to create resources and reduce the effects of environmental risk. The ability of firms to meet their set targets depends on how well the firm can interact with its external environment. How the firm interacts with its external environment, according to Jogaratnam (2017), explains the strategic orientation of the firm. Therefore, this theory can be said to explain the link between strategic orientation and organizational performance, which are the variables of this paper.

\section{Strategic orientation}

Valos and Bednall (2010) explain that one of the most important pillars that has major implications for the structure, activities, investments, relationships with the market and performance of an organization is strategy. Sarker and Palit (2015) are of the view that having a strategy helps organizations find solutions, create new capabilities, and improve business performance as organizations interact with the external environment. Managers of such organizations through such interactions are able to gather specific resources, recognize opportunities for providing valued products and services, and to convey those products and services for higher profits (Al-Ansaari, Bederr \& Chen, 2015). Obeidat (2016) is also of the view that adopting the best strategy out there requires organizations to co-ordinate their approaches in establishing industry positions and/or by relying on their resources, competences, and capabilities in an effort to achieve a fit with their internal and external 
environments and, in turn, achieve a sustained competitive advantage and improved business efficiency.

Further, one of the early classifications of strategic orientation was done in the study of Miles, Snow, Meyer and Coleman (1978). Their approach to strategic orientation was termed the classificatory approach. This approach, according to McKelyey (1975), attempts to group strategies on either a priori conceptual grounds or derived categorizations. Respectively referred to as typologies (e.g., Hofer \& Schendel, 1978; Porter, 1985; Rumelt, 1982; Wissema, Van der Pol \& Messer, 1980) and taxonomies (e.g., Miller \& Friesen, 1978), this approach aggregates firms according to the nature of strategy emphasized. For instance, the Miles et al. (1978) strategic typology has been widely examined in the marketing literature (McDaniel \& Kolari, 1987; McKee, Varadarajan \& Pride, 1989; Speed, 1993) and suggests that firms can be affiliated to one of four strategy types: prospector; (2) defender; (3) analyser; and (4) reactor. Notwithstanding this, Tiryakian (1968) accentuates that the classificatory schemas are restricted to inter-group comparison and do not allow for intra-group investigation. In addition, Speed (1993) opined that although firms may adopt different strategic orientations that can be meaningfully classified, such parsimonious approaches may not detect nuances associated with various aspects of competitive strategy, because crude categorizations do not acknowledge the importance of dimensions that are excluded from the typology.

Bing and Zhengping (2011) also classified strategic orientation into a mix, covering entrepreneurial orientation, marketing orientation and learning orientation. Therefore, Bing and Zhengping (2011) explained the entrepreneurial orientation as a new entry of a company and the procedures, practice, and decision-making activities, with the aim of improving the value of products and services in response to 
customers, which can lead to excellent performance. Lumpkin and Dess (1996) explored five dimensions of entrepreneurial orientation, including autonomy, proactiveness, aggressiveness, risk-taking and innovativeness, which are similar to the categorization of most of the studies on strategic orientation.

Based on the various conceptualization of strategic orientation, the current study, therefore, adopts the framework developed by Venkatraman (1989), who conceptualized strategic orientation in terms of six dimensions: aggressiveness, analysis, defensiveness, futurity, proactivity and riskiness. The choice of this categorization of strategic orientation is deeply rooted in the explanation provided in the study of Miller (1983). Venkatraman (1989) in his study developed six types of strategic orientation that apply in this study. These are leading (always trying to innovate), future-analytic (focusing on research for future activities), aggressive (undercutting competitors), defensive (maintaining careful control), adventurous (risk taking), and conservative (avoiding risk). The conceptualization of strategic orientation by Venkatraman (1989) has since been used in several studies (Han, 2012, Han \& Verma, 2012) and is also central to the various classifications of strategic orientation as it consolidates the various classifications given by researchers.

\section{Organizational Performance \\ Numerous authors} (Chen, 2007; Evans, 2005) underline that the main empirical contributions to the measurement of performance of businesses have focused on the industrial sector and some segments in the service sector (banks, retail, insurance), but have neglected the travel and tourism sector. However, from the 1990s onwards, many studies have focused on performance in the hotel sector (Okumus, 2002). These studies that have focused on the hotel sector have limited their studies to features of hotel businesses (Winata \& Mia, 2005; Mia \& Patiar, 2001; Brander Brown \& Harris, 1998), which 
comprise business units such as rooms, food and beverage and stores.

Cui and $\mathrm{Hu}$ (2012) posit that measurement of corporate performance has always been the unique question that researchers are trying to answer. Wadongo, Odhuno, Kambona, and Othuon (2010) explain that performance of an organization has traditionally been measured by looking at the revenues or the profits made at the end of the year, or using key financial ratios. Despite the development of performance measurement systems in the hospitality industry, various researchers (Brander-Brown \& McDonnell, 1995; Atkinson \& BranderBrown, 2001; Harris \& Mongiello, 2001) have pointed to the reluctance of the hospitality industry to use balanced measures and rely solely on financial measures. However, Orgaad, Larsen and Marnburg (2008) are of the view that no single indicator will give a comprehensive picture of performance of a firm. Therefore, this calls for the use of different performance measures.
Several constructs have been used to measure financial performance of firms often referred to as the accounting measurement of performance. These measurements, according to Hermalin and Weisbach (1991); Barney (1986), include profit rate, return on assets (ROA), long-term profitability, sales growth rate. Calori and Sarnin (1991) also used the return-on-investment ratio, the return on sales ratio and the annual variation of the net turnover, which are all financial variables in measuring performance of a firm. What is common to researchers in the field of organizational performance is the use of these accounting measurement of organizational performance. For example, Nzioka and Njuguna (2017); Jogartnam (2017); Han and Verma (2012); Li, Lam and Qian (2001); Bagozzi, Verbeke and Gavino (2003); Fisher and Alford (2000) etc. All introduced accounting measurement in measuring corporate performance.

Other studies have also indicated that non-financial 
indexes, such as employee satisfaction, customer satisfaction, turnover rate, quality of products/services, and some other variables in the organizational aspects should also be used in measuring performance (Cui \& Hu, 2012). Besides these indexes, Kaplan and Norton (2007) also raised the balance score card to emphasize the importance of customer, internal business processes, learning and growth. Bagozzi et al. (2003) also divided corporate performance into the in-role performance and extra-role performance. In-role performance includes sales volume, communication effectiveness, and relationship building, while extra-role performance is made up of courtesy, helping, sportsmanship, and civic virtue. Researchers have argued that the non-financial variable is the new trend for appraising organizational performance. The development of the employee behaviour and the consciousness of social responsibilities are all considered as equally important as the accounting variables measure of organizational performance (Calori \& Sarnin, 1991).

Numerous studies have examined the significance of strategic orientation and its impact on firm performance. Gatignon and Xuereb (1997), in a survey of 393 marketing executives, found a positive relationship between strategy and performance. Their results confirmed that the influence of strategic orientation on firm performance depended on the uncertainty level in the market that would increase customer orientation, therefore, increasing overall performance in a company. An analysis of the extant literature indicates that few studies have assessed the impact of strategic orientation on small and medium firms of which the hotel sector prominently features. Avci, Madanogu and Okumus (2011) looked at strategic orientation and performance of tourism firms with evidence from a developing country, Turkey. The study also established that prospectors were found to 
outperform defenders, while analyzers showed comparable performance to prospectors. The study, therefore, recommended that both perceptual and objective measures are needed to confirm the results to better assess the possible differences in performance among strategic orientations in some other developing countries.

Similarly, in a study by

Han and Verma (2012), to explore the relationship between strategic orientation, corporate culture and financial performance of hotels in South Korea, the study established that opportunity-seeking approach of a leading strategic orientation drove financial results for the clan and adhocracy cultures, but did not help the market or hierarchy cultures. Other strategic orientation also drove financial results, including future-analytic and defensive. Obeidat (2016) examined the effect of both strategic orientation and innovation on organizational performance. Data for the study were collected from 252 employees of three major telecommunication companies operating in Jordan. The results of the study established that there is a significant relationship between strategic orientation, bank performance, and business strategy. Furthermore, the results of the study indicated that business strategy plays a mediator role in the relationship between strategic orientation and firm performance.

Jassmy and Bhaya (2016) also examined the effects of strategic orientation and its effects on the organizational performance of real estate banks in the Al-Dewaniya province of Iraq. The study concluded that strategic orientation positively influenced organizational performance when only customer orientation is used as a measure of strategic orientation. However, when competitive orientation is used to measure strategic orientation, the relationship with organizational performance is insignificant. Nasir, Al Manum and Breed (2017) also examined the effect of strategic orientation on the performance of small scale and medium enterprises in Malaysia. 
The results of the study showed that entrepreneurial orientation was the construct that shares a positive relationship with all the other constructs in the model. Therefore, the entrepreneurial orientation was identified as the most significant strategic orientation.

Further, Nzioka and Njuguna (2017) also investigated the relationship between firm orientation and performance of hotels in Nairobi County, Kenya. Firm orientation was measured using market structure, organizational structure, strategic orientation and market orientation while performance of hotels was also measured using customer satisfaction, employee commitment, overall business performance, sales, profits, return on investment (ROI), return on assets (ROA) and return on sales (ROS). The study established that lower business performers were associated with defensiveness and aggressiveness, while high performers were associated with analysis, futurity, proactiveness, based on the comparative approach developed by
Venkatraman (1989). The study further established that strategic orientation and performance of hotels were positively and significantly related. Based on the empirical review, the study, therefore, hypothesizes that strategic orientation types positively affect both financial and non-financial performance of star-rated hotels in Ghana.

\section{Methodology}

This section of the paper describes the methods employed in collecting, analysing and interpreting data used for the study. It describes how the variables of the study were measured, the population of the study, sample and sampling technique used, instrument used for data collection, as well as the statistical tools used for the analysis. Details of the methods are described in the subsequent sessions of this paper.

\section{Measurement of variables}

Two key variables were of interest in this study; strategi orientation and organizational performance. The measurement of these variables was informed 
by literature review. Details of the description of the variables are discussed.

\section{Strategic orientation}

Measurement of strategic orientation was adapted from Venkatraman (1989). Six strategic orientation types were identified. These are: aggressive, analytic, defensiveness, futuristic, proactive and riskiness. The conceptualization of strategic orientation by Venkatraman (1989) has since been used in several studies (Han, 2012; Han \&Verma, 2012) and is also central to the various classifications of strategic orientation as it consolidates the various classifications given by researchers.

\section{Organizational Performance}

With respect to the measurement of organizational performance, both financial and non-financial indicators were used. Financial indicators relied on subjective approaches to measuring financial performance. Justifications provided for the use of subjective measurement of performance are: owners/managers unwillings to disclose actual figures of their performance for fear of being taxed or for being targeted by the government (Zulkiffli \& Perera, 2011).

The use of non-financial measures was also informed by Kaplan and Norton (1992). Twelve items were used to measure both financial and nonfinancial organizational performance namely profitability, return on investment, growth in profitability, daily sales, increment in volume of sales, retaining customers, supplier relations, quality of service delivery, occupancy rate, size of customers and productivity of our employees compared to industry average.

Sample size and sampling procedure

Based on the total population of 680 managers of star-rated hotels, a sample of 248 hotel managers were chosen based on the table developed by Krejcie and Morgan (1970). The respondents were then selected, using the stratified random 
sampling technique. The population was divided into five (5) strata. The groups were managers and supervisors of five star-rated hotels, four star-rated hotels, three star-rated hotels, two star-rated hotels and one star-rated hotels. A proportion of each stratum was calculated to get the number of respondents for each stratum based on the sample size of 248. Next, respondents were randomly selected until the sample for each stratum was obtained.

\section{Instrument}

Questionnaire was the main data collection instrument used for the study. The questionnaire comprised three sections; Section A, B, and C. Section A collected data on the strategic orientations of the starrated hotels, Section B focused on organizational performance and Section $\mathrm{C}$ also focused on demographic characteristics of the respondents and hotels involved in the study. In all, 29 items were used to measure strategic orientation, 12 items were used to measure both financial and non-financial organizational performance. Five items were used to collect data on the demographic characteristics of respondents. Of the 248 questionnaires distributed, 178 were received and used for analysis, representing a response rate of $71.72 \%$.

Data Analysis

Data preparation was in two stages. Firstly, the raw data collected through the questionnaire were edited, coded and converted into the actual variables of interest. Upon receipt, each questionnaire was carefully checked for incompleteness and inconsistencies. Of a total of 248 questionnaires distributed, 178 of the questionnaires received were considered valid for data analysis after screening and eliminating uncompleted questionnaires. The processed data was then analyzed using partial least squares in structural equation modeling. PLS-SEM is widely recognized for its remarkable advantages in behavioural studies (Hair, Ringle 
\& Sarstedt, 2011), as it helps researchers understand the relationship among sets of observed variables (Hair, Hult, Ringle \& Sarstedt, 2016).

\section{Results and Discussion}

This session of the article presents the results of the study emanating from the analysis carried out. First, a description of the respondents was provided. In the outcome is presented in the subsequent sessions.

Demographic characteristics of respondents

A preliminary analysis was carried out to examine the demographic information of the respondents. Findings are presented in Table 1. Table 1 presents the demographic characteristics of the respondents. Out of a total of 178 respondents, 99 were males and 79 were females representing $55.62 \%$ and $44.38 \%$ respectively. The domination of men in the sector was due to the nature of the task and responsibilities associated with the role of a hotel manager. addition, three models were used to analyse the hypothesized relationship. The first model sought to analyse the composite effect of strategic orientation on performance. The second model examined the constructs used in measuring strategic orientation against financial performance and the third model also analysed the individual constructs of strategic orientation against nonfinancial performance. Details of Regarding the age distribution of the respondents, 31 were between 18 and 24 years of age. Seventy-four were also between 25-31 years old, representing $41.57 \%$. Forty-nine of the respondents were also aged between 32-38 representing $27.53 \%$. Thirteen were aged between $39-44,6 \%$ were also aged between 45-51, representing $7.30 \%$ and $3.37 \%$, respectively. Most of the managers were young and energetic considering the demands of the work, and they were more suited for such a job. This is explained by the large percentage of the managers that are aged between 18-38. 
Table 1: Demographic characteristics of respondents and star-rated hotels

\begin{tabular}{|c|c|c|}
\hline Item & Frequency & Percentage $(\%)$ \\
\hline \multicolumn{3}{|l|}{ Sex } \\
\hline Male & 99 & 55.62 \\
\hline Female & 79 & 44.38 \\
\hline Total & 178 & 100 \\
\hline \multicolumn{3}{|l|}{ Age } \\
\hline $18-24$ & 31 & 17.42 \\
\hline $25-31$ & 74 & 41.57 \\
\hline $32-38$ & 49 & 27.53 \\
\hline $39-44$ & 13 & 7.30 \\
\hline $45-51$ & 6 & 3.37 \\
\hline 52 and above & 5 & 2.81 \\
\hline Total & 178 & 100 \\
\hline \multicolumn{3}{|l|}{ Level of education } \\
\hline Senior high school or lower & 40 & 22.5 \\
\hline $\begin{array}{l}\text { Higher National Diploma } \\
\text { (HND) }\end{array}$ & 56 & 31.5 \\
\hline First Degree & 61 & 34.3 \\
\hline Postgraduate Degree & 21 & 11.8 \\
\hline Total & 178 & 100 \\
\hline \multicolumn{3}{|l|}{ Work experience } \\
\hline $1-5$ years & 97 & 54.49 \\
\hline $6-10$ years & 54 & 30.34 \\
\hline $11-15$ years & 11 & 6.18 \\
\hline 16 years and above & 16 & 8.99 \\
\hline Total & 178 & 100 \\
\hline \multicolumn{3}{|l|}{ Position } \\
\hline Assistant manager & 25 & 14.05 \\
\hline Manager & 47 & 26.41 \\
\hline Senior manager & 11 & 6.18 \\
\hline Supervisor & 95 & 53.37 \\
\hline Total & 178 & 100 \\
\hline \multicolumn{3}{|l|}{ Ownership structure } \\
\hline Company & 112 & 62.92 \\
\hline Partnership & 4 & 2.25 \\
\hline Sole proprietor & 62 & 34.83 \\
\hline Total & 178 & 100 \\
\hline Number of rooms & 2987 & \\
\hline Number of employees & 2107 & \\
\hline
\end{tabular}

Source: Field survey (2018) 
Five of the respondents were also over 51 years of age, representing 2.81 percent. Table 7 shows that more than $50 \%$ of the respondents were between the ages of 18 and 38. In terms of academic qualification, most of the respondents had qualifications ranging from Higher National Diploma, First Degree and Post Graduate Degree. Fifty-six of the respondents were HND holders representing $31.5 \%$, 61 were first degree holders representing 34.3 and 21 had a post graduate degree representing 11.8 percent. Forty of the respondents representing 22.5 percent were SHS holders.

This indicates the respondents were educated and could understand and respond to the issues of corporate culture, strategic orientation and performance of the hotels they managed. To support this point, respondents also held positions ranging from supervisor to manager, which made them well placed to understand the corporate culture, strategic orientation of their respective hotels. Ninety-five of the respondents were supervisors representing 53.37 percent. Forty-seven of the respondents were managers representing 26.41 percent. Twenty-five of the respondents were also assistant managers representing 14.05 and 11 of the respondents were also senior managers also representing 6.18 percent. With respect to the ownership structure of the star-rated hotels, the study found out that 112 of the hotels involved in the study were registered as Limited Liability Companies representing $62.9 \%, 4$ were registered as partnership and 62 were also registered as sole proprietorship representing $2.24 \%$ and $34.8 \%$ respectively. The hotels involved in the study also employed 2107 persons. The hotels involved in the study also supplies 2987 rooms to their customers.

\section{Effect of strategic orientation on organizational performance}

First, the study sought to determine whether the linkage between strategic orientation and 
performance, as established through the literature reviewed, were also applicable to the Ghanaian context. To achieve this, the study hypothesized that strategic orientation has a significant effect on performance of star-rated hotels. A model (Figure 1) was developed and tested to answer this objective and also to test the hypothesis. Details of the findings are presented in the subsequent sections. Before analyzing the proposed model on the relationship between strategic orientation and organisational performance of star-rated hotels, the reliability and validity of the model were evaluated and established (see Tables 2 and 3). Then to estimate reflective measurement models, outer loadings, Composite reliability, average variance extracted, and discriminant validity were evaluated.

Table 2: Criteria for the evaluation of the model (Reliability and Validity)

\begin{tabular}{lrrrrrr}
\hline Variables & $\begin{array}{r}\text { Cronbach's } \\
\text { Alpha }\end{array}$ & rho_A & $\begin{array}{r}\text { Composite } \\
\text { Reliability }\end{array}$ & & AVE & Adjusted \\
square & R square \\
$\begin{array}{l}\text { Performance } \\
\begin{array}{l}\text { Strategic } \\
\text { orientation }\end{array}\end{array}$ & 0.7207 & 0.8051 & 0.8145 & 0.5262 & 0.3146 & 0.3107 \\
\hline
\end{tabular}

Source: Field survey (2018).

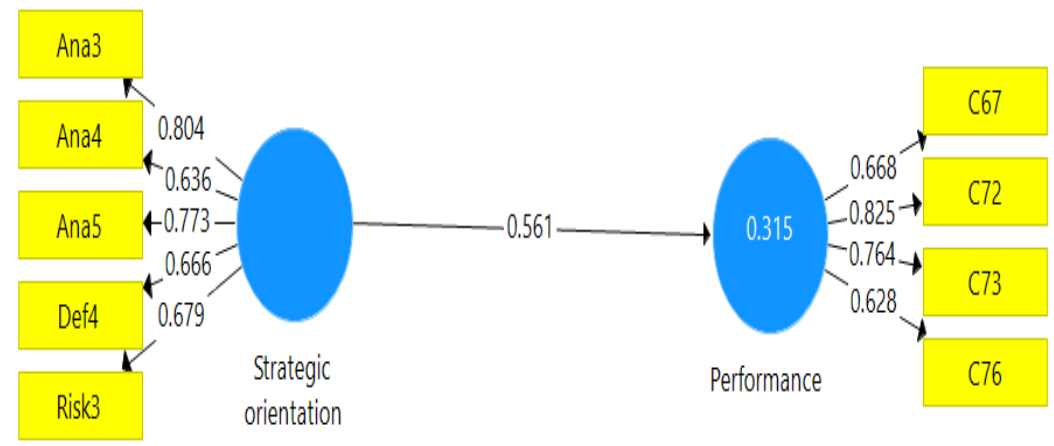

Figure 1: Model depicting the composite effect of strategic orientation on Performance

Source: Field Survey (2018) 
Table 3: Discriminant Validity Using Fornell-Larcker Criterion

\begin{tabular}{lcc}
\hline Variables & Performance & $\begin{array}{c}\text { Strategic } \\
\text { orientation }\end{array}$ \\
Performance & 0.7254 & \\
Strategic orientation & 0.5608 & 0.7146 \\
\hline
\end{tabular}

Source: Field survey (2018

Examination of the outer loadings of the latent variables (strategic orientation and performance) indicates that the loadings are between 0.628 and 0.825 (Figure 1). Composite reliability and AVE scores are above 0.7 and 0.5 , indicating good reliability and validity, respectively. The FornellLarcker criterion indicates that there is discriminant validity between the cross loadings. The predictive abilities of the structural model were also evaluated, using the $\mathrm{R}^{2}$ coefficient of determination, which recorded 0.3146, indicating that 31.46 of the performance was explained by strategic orientation.

To check if the path coefficients of the inner model are significant or not (TStatistics), bootstrapping procedure was run. Using a twotailed t-test with a significant level of 5\%, the path coefficient should be significant if the $\mathrm{T}$ statistics is larger than 1.96. In the current study, the T-Statistics recorded 11.4235, which is greater than the 1.96. The study, therefore, found a statistically significant effect of strategic orientation on hotel performance. Further, the model's effect size $\left(f^{2}\right)$, which showed how much an exogenous latent variable contributes to an endogenous latent variable's $\mathrm{R}$ square value, highlight large effect of 0.4589 . The predictive relevance of the model was also assessed, using the StoneGeisser $\mathrm{Q}$ test. The $\mathrm{Q}^{2}$ values for the endogenous variable should be above zero (0). Cohen (1998) provides a guideline for assessing $\mathrm{Q}^{2}$. From 0.02-0.14 is considered weak, $0.15-0.34$ is moderate and 0.35 and above is considered strong. Therefore, based on the loadings presented 
in Table 4, the $\mathrm{Q}^{2}$ is 0.136 ; this means the predictive relevance of the model is considered weak. This suggests that strategic orientation compositely is a weak predictor of performance of star-rated hotels.

Table 4: Stone-Geisser Q-test for model one

\begin{tabular}{lrrr}
\hline Constructs & SSO & SSE & $\begin{array}{r}\mathrm{Q}^{2}(=1- \\
\mathrm{SSE} / \mathrm{SSO})\end{array}$ \\
\hline Performance & 712.000 & 615.026 & 0.136 \\
Strategic Orientation & 890.000 & 890.000 & \\
\hline
\end{tabular}

Source: Field Survey (2018)

The study then sought to determine which of the strategic orientation types was responsible for the significant influence it had on performance. To achieve this, the types of strategic orientation were modeled against financial performance. A second model was proposed, which depicted the strategic orientation types as predictors of financial performance. Details of the outcome are presented in Figure 2 and Table 5 . The validity of the model was also assessed using the Fornell-Larcker criterion. The results are presented in Table 6.

Table 5: Criteria for evaluating model two

\begin{tabular}{lrrrrr}
\hline Constructs & $\begin{array}{l}\text { Cronbach's } \\
\text { Alpha }\end{array}$ & $\begin{array}{l}\text { Composite } \\
\text { Reliability }\end{array}$ & $\begin{array}{l}\text { Average } \\
\text { Variance } \\
\text { Extracted } \\
\text { (AVE) }\end{array}$ & $\mathrm{R}^{2}$ & $\begin{array}{l}\text { Adjusted } \\
\mathrm{R}^{2}\end{array}$ \\
\hline Aggressiveness & 0.674 & 0.786 & 0.557 & & \\
$\begin{array}{l}\text { Analytic } \\
\text { Defensiveness }\end{array}$ & 0.735 & 0.833 & 0.556 & & \\
Financial & 0.657 & 0.793 & 0.567 & 0.080 & 0.059 \\
performance & 0.835 & 0.872 & 0.633 & & \\
Futuristic & 0.624 & 0.801 & 0.578 & & \\
\hline
\end{tabular}

Notes: Loadings between 0.4 and 0.7 are acceptable. $>0.7$ is high. Cronbach's $\alpha>0.7$ is acceptable and high. Composite reliability should be 0.7 or higher. AVE should be 0.5 or higher. $R^{2}$ of 0.75 is substantial, 0.50 is moderate, and 0.25 is weak.

Source: Field Survey (2018) 


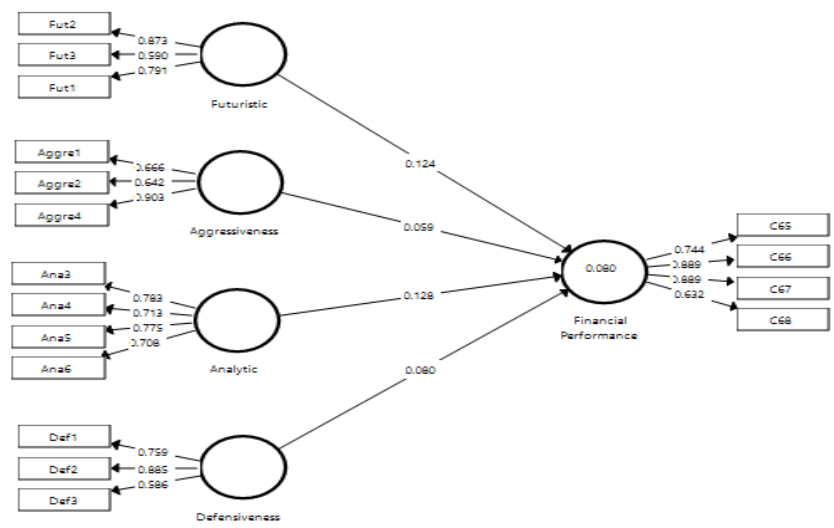

Figure 2: Model depicting the effect of strategic orientation on financial performance

Source: Field Survey (2018)

An examination of the outer loadings for the second model indicates that the loadings of the latent variables are between 0.586 and 0.903 . However, proactive and riskiness strategic orientations failed to meet the quality criteria after a number of iterations. Further, of the remaining four constructs of strategic orientation, some had loadings below 0.7. Since removing those loadings did not change the overall reliability, the items remained in the model.
Composite reliability scores were all above 0.7. Average variance extracted scores were also above 0.5. These indicate good reliability and validity of the model. The outcome in Table 6 shows that there is discriminant validity between all the constructs based on the crossloading criteria. The $\mathrm{R}^{2}$ figure meant that aggressiveness, analytic, defensiveness and futuristic weakly explains $8 \%$ of the variable in financial performance. 
Table 6: Discriminant Validity Using Fornell-Larcker Criterion

\begin{tabular}{|c|c|c|c|c|c|}
\hline Constructs & $\begin{array}{l}\text { Aggressiven } \\
\text { ess }\end{array}$ & $\begin{array}{l}\text { Analyt } \\
\text { ic }\end{array}$ & $\begin{array}{l}\text { Defensiven } \\
\text { ess }\end{array}$ & $\begin{array}{l}\text { Financial } \\
\text { performan } \\
\text { ce }\end{array}$ & $\begin{array}{l}\text { Futurist } \\
\text { ic }\end{array}$ \\
\hline $\begin{array}{l}\text { Aggressiven } \\
\text { ess }\end{array}$ & 0.746 & & & & \\
\hline Analytic & 0.255 & 0.746 & & & \\
\hline $\begin{array}{l}\text { Defensivene } \\
\text { ss }\end{array}$ & -0.004 & 0.408 & 0.753 & & \\
\hline $\begin{array}{l}\text { Financial } \\
\text { performance }\end{array}$ & 0.141 & 0.233 & 0.170 & 0.796 & \\
\hline Futuristic & 0.397 & 0.469 & 0.309 & 0.232 & 0.761 \\
\hline
\end{tabular}

Source: Field work (2018)

Bootstrapping procedure was done to determine the significance of the path coefficients. The based-on-thebootstrapping scores for aggressiveness, proactiveness, riskiness, defensiveness, futuristic and analytic all indicated that these strategic orientations were not significant in predicting financial performance. Results are presented in Table 7.

To confirm the scores of the bootstrapping, the $f^{2}$ scores were generated, which also recorded scores lower than 0.02 , indicating small effect size. Further, the predictive relevance of the model was also assessed, using Stone-Geiser $\mathrm{Q}$ test. The $\mathrm{Q}^{2}$ as shown in Table 8 is within the range of $0.02-0.14$, signifying weak predictive relevance.

The study also sought to find out whether strategic orientation was also a predictor of non-financial performance. To this end, a third model was developed to test the effect of strategic orientation types on non-financial performance. Details of the outcome are presented in Figure 3, Tables 9 and 10 .

An examination of the outer loadings of the latent variable indicates that loadings are between 0.7 and 1.0. However, proactiveness failed to 
meet the quality criteria after a number of iterations was removed from the model. The other remaining five constructs of strategic orientation had loadings above 0.7. The discriminant validity, which was determined according to FornellLarcker's (1981) criterion.

Table 7: Bootstrapping Results and T-Statistics for Path Coefficients of Model Two

\begin{tabular}{|c|c|c|c|c|c|}
\hline Constructs & $\begin{array}{l}\text { Original } \\
\text { Sample } \\
\text { (O) }\end{array}$ & $\begin{array}{l}\text { Sample } \\
\text { Mean } \\
\text { (M) }\end{array}$ & $\begin{array}{l}\text { Standard } \\
\text { Deviation } \\
\text { (STDEV) }\end{array}$ & $\begin{array}{l}\text { T Statistics } \\
(|\mathrm{O} / \mathrm{STDEV}|)\end{array}$ & $\begin{array}{l}\mathrm{P} \\
\text { Values }\end{array}$ \\
\hline $\begin{array}{l}\text { Aggresiveness } \\
\text {-> Financial } \\
\text { performance }\end{array}$ & 0.059 & 0.052 & 0.121 & 0.489 & 0.625 \\
\hline $\begin{array}{l}\text { Analytic -> } \\
\text { Financial } \\
\text { performance }\end{array}$ & 0.128 & 0.136 & 0.104 & 1.229 & 0.219 \\
\hline $\begin{array}{l}\text { Defensiveness } \\
\text {-> Financial } \\
\text { performance }\end{array}$ & 0.080 & 0.109 & 0.122 & 0.654 & 0.513 \\
\hline $\begin{array}{l}\text { Futuristic -> } \\
\text { Financial } \\
\text { performance }\end{array}$ & 0.124 & 0.122 & 0.089 & 1.383 & 0.167 \\
\hline \multicolumn{6}{|c|}{ Source: Field survey (2018). } \\
\hline \multicolumn{6}{|c|}{ Table 8: Stone-Geisser Q-test for Model Two } \\
\hline Constructs & \multicolumn{2}{|r|}{ SSO } & SSE & \multicolumn{2}{|c|}{$\mathrm{Q}^{2}(=1-\mathrm{SSE} / \mathrm{SSO})$} \\
\hline Aggressive & \multicolumn{2}{|r|}{534.000} & \multicolumn{2}{|c|}{534.000} & \\
\hline Analytic & \multirow{2}{*}{\multicolumn{2}{|c|}{$\begin{array}{l}712.000 \\
534.000\end{array}$}} & \multicolumn{2}{|c|}{712.000} & \\
\hline Defensive & & & \multicolumn{2}{|c|}{534.000} & \\
\hline Financial & \multicolumn{2}{|r|}{712.000} & \multirow{2}{*}{\multicolumn{2}{|c|}{695.154}} & 0.024 \\
\hline Performance & \multirow{2}{*}{\multicolumn{2}{|c|}{534.000}} & & & \\
\hline Futuristic _ & & & \multicolumn{2}{|c|}{534.000} & \\
\hline
\end{tabular}

Source: Field survey (2018). 
Table 9: Criteria for the Evaluation of the Model (Reliability and Validity)

\begin{tabular}{lccccc}
\hline Constructs & $\begin{array}{c}\text { Cronbach's } \\
\text { Alpha }\end{array}$ & $\begin{array}{c}\text { Composit } \\
\mathrm{e} \\
\text { Reliabilit } \\
\mathrm{y}\end{array}$ & $\begin{array}{c}\text { Average } \\
\text { Variance } \\
\text { Extracted } \\
\text { (AVE) }\end{array}$ & $\mathrm{R}^{2}$ & $\begin{array}{c}\text { Adjusted } \\
\mathrm{R}^{2}\end{array}$ \\
\hline Aggressiveness & 0.760 & 0.845 & 0.578 & & \\
Analytic & 0.701 & 0.833 & 0.624 & & \\
$\begin{array}{l}\text { Defensiveness } \\
\text { Futuristic }\end{array}$ & 1.000 & 1.000 & 1.000 & & \\
$\begin{array}{l}\text { Non-financial } \\
\text { performance }\end{array}$ & 0.724 & 0.879 & 0.784 & 0.422 & 0.406 \\
Riskiness & 0.649 & 0.849 & 0.738 & & \\
\hline
\end{tabular}

Notes: Loadings between 0.4 and 0.7 are acceptable. $>0.7$ is high. Cronbach's $\alpha>0.7$ is acceptable and high. Composite reliability should be 0.7 or higher. AVE should be 0.5 or higher. $R 2$ of 0.75 is substantial, 0.50 is moderate, and 0.25 is weak

Source: Field Survey (2018).

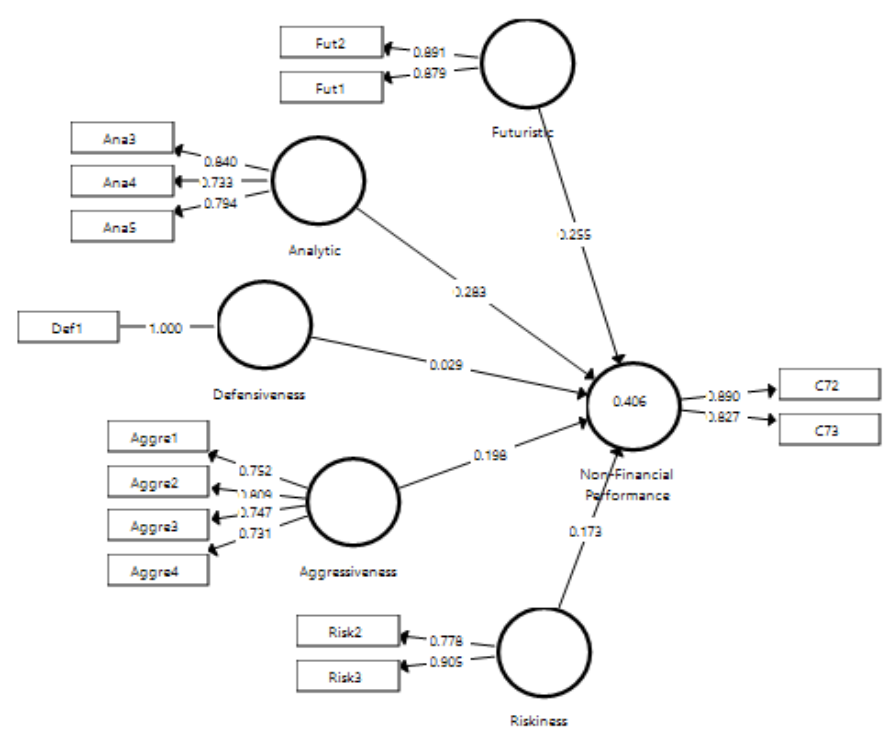

Figure 3: Model Depicting the Effect of Strategic Orientation Types on NonFinancial Performance

Source: Field Survey (2018) 
Table 10: Discriminant Validity Using Fornell-Larcker

\begin{tabular}{lrrrrr}
\hline Constructs & Aggressiveness & Analytic & Defensiveness & Futuristic & $\begin{array}{l}\text { Non- } \\
\text { financial } \\
\text { performance }\end{array}$ \\
\hline Aggressiveness & 0.760 & & & & \\
Analytic & 0.170 & 0.790 & & & \\
Defensiveness & 0.271 & 0.447 & 1.000 & & \\
Futuristic & 0.403 & 0.363 & 0.360 & 0.885 & \\
Non-financial & 0.364 & 0.507 & 0.427 & 0.465 & 0.859 \\
performance & 0.092 & 0.519 & 0.223 & 0.128 & 0.380 \\
Riskiness & & & & & \\
\hline
\end{tabular}

Source: Field Survey (2018)

The values indicated there is discriminant validity between all the constructs based on the cross-loading criterion. Once the construct measurement was confirmed as reliable and valid, the study assessed the structural model's predictive abilities and the relationships between the model components.

As shown in Figure 3, the coefficient of determination, which is the $\mathrm{R}^{2}$, is 0.422 , explained $42.2 \%$ of the variances in non-financial performance.
Numbers on the arrow, which are called the path coefficients, displayed how strong the effect of one variable is on the other variable. The weight of each path coefficients allows the researcher to rank the variables' statistical importance. The model, as presented in Figure 3, shows that analytic strategic orientation makes a very strong effect on nonfinancial performance with scores of 0.283 . 
Futuristic follows with scores of 0.255 , aggressiveness is next with scores of 0.198 , riskiness is next with scores of 0.173 and defensiveness with scores of 0.029 (Figure 3). All the path relationships were all statistically significant except for defensiveness that recorded a path score less than 0.1 .

To check if the path coefficients of the inner model are significant or not (TStatistics), bootstrapping procedure was run. Using a twotailed $t$-test with a significance level of $5 \%$, the path coefficient should be significant if the $T$ statistics is larger than 1.96. In the present study, as shown in Table 11, futuristic, analytic, aggressiveness and riskiness all recorded T-statistics scores greater than 1.96 except for defensiveness that recorded scores less than 1.96. Based on the bootstrapping scores, the following strategic orientation types were found to be significant predictors of nonfinancial performance: analytic strategic orientation; futuristic strategic orientation and riskiness strategic orientation.

Table 11: Bootstrapping Results and T-Statistics for Path Coefficients (Inner Model)

\begin{tabular}{lccccc}
\hline Constructs & $\begin{array}{c}\text { Original } \\
\text { Sample } \\
(\mathrm{O})\end{array}$ & $\begin{array}{c}\text { Sample } \\
\text { Mean } \\
(\mathrm{M})\end{array}$ & $\begin{array}{c}\text { Standard } \\
\text { Deviation } \\
(\text { STDEV })\end{array}$ & $\begin{array}{c}\text { T Statistics } \\
(|\mathrm{O} / \mathrm{STDEV}|)\end{array}$ & $\begin{array}{c}\mathrm{P}- \\
\text { values }\end{array}$ \\
$\begin{array}{l}\text { Aggressiveness } \\
->\text { Non-financial } \\
\text { performance }\end{array}$ & 0.198 & 0.204 & 0.069 & 2.864 & 0.004 \\
$\begin{array}{l}\text { Analytic -> Non- } \\
\text { financial } \\
\text { performance }\end{array}$ & 0.283 & 0.282 & 0.073 & 3.863 & 0.000 \\
$\begin{array}{l}\text { Defensiveness -> } \\
\text { Non-financial } \\
\text { performance }\end{array}$ & 0.029 & 0.032 & 0.071 & 0.402 & 0.688 \\
$\begin{array}{l}\text { Futuristic -> } \\
\text { Non-financial } \\
\text { performance }\end{array}$ & 0.255 & 0.252 & 0.079 & 3.211 & 0.001 \\
$\begin{array}{l}\text { Riskiness -> } \\
\text { Non-financial } \\
\text { performance }\end{array}$ & 0.173 & 0.177 & 0.068 & 2.530 & 0.011 \\
\hline
\end{tabular}

Source: Field survey (2018) 
However, the following strategic orientation types were also found not to significantly predict nonfinancial performance: defensiveness and proactiveness. The model's effect size $\left(f^{2}\right)$, which showed how much an exogenous latent variable contribute to an endogenous latent variable's $\mathrm{R}^{2}$ value, highlights small effect sizes as the scores were all lower than 0.15 . The predictive relevance of the model was also assessed, using the Stone-Geisser Q-test. The model's predictive relevance was 0.275 , which is within the range of $0.15-0.34$ a moderate predictive relevance. The results of these tests are presented in Tables 12 and 13.

Table 12: Effect Size of Structural Model Six $\left(\mathrm{f}^{2}\right)$

\begin{tabular}{lc}
\hline Constructs & Non-financial performance \\
\hline Aggressiveness & 0.053 \\
Analytic & 0.085 \\
Defensiveness & 0.001 \\
Futuristic & 0.078 \\
Non-financial & \\
performance & \\
Riskiness & 0.034 \\
\hline
\end{tabular}

Notes: Effect size of $0.02,0.15$, and 0.35 indicates small, medium, and large effect, respectively (Marcoulides \& Saunders, 2006).

Source: Field Survey (2018)

Table 13: Stone-Geisser Q-test for Model Three

\begin{tabular}{lcrr}
\hline Constructs & SSO & SSE & $\mathrm{Q}^{2}(=1-\mathrm{SSE} / \mathrm{SSO})$ \\
\hline Aggressive & 712.000 & 712.000 & \\
Analytic & 534.000 & 534.000 & \\
Defensive & 178.000 & 178.000 & \\
Futuristic__ & 356.000 & 356.000 & 0.275 \\
Non-Financial & 356.000 & 258.278 & \\
Performance & & & \\
Riskiness_ & 356.000 & 356.000 & \\
\hline
\end{tabular}

Source: Field Survey (2018) 
Summary of the hypotheses tested are presented in Table 14. Table 14 highlights the key outcomes in predicting the effect of strategic orientation on the performance of star-rated hotels in Ghana.

Table 14: Summary Results of Hypotheses Testing of Models one, two and three

\begin{tabular}{|c|c|c|c|c|}
\hline Hypotheses & $\begin{array}{c}\text { Path } \\
\text { coefficients }\end{array}$ & $\begin{array}{c}\mathrm{T}- \\
\text { statistics }\end{array}$ & $\begin{array}{c}\mathrm{P}- \\
\text { value }\end{array}$ & Results \\
\hline $\begin{array}{l}\text { Strategic orientation > } \\
\text { organizational performance }\end{array}$ & $0.5608 * *$ & 11.4235 & 0.0000 & $\begin{array}{r}\text { Fail to } \\
\text { reject }\end{array}$ \\
\hline $\begin{array}{l}\text { Aggressiveness > financial } \\
\text { performance }\end{array}$ & 0.059 & 0.489 & 0.625 & Rejected \\
\hline $\begin{array}{l}\text { Proactiveness > financial } \\
\text { performance }\end{array}$ & & & & \\
\hline $\begin{array}{l}\text { Riskiness }>\text { financial } \\
\text { performance }\end{array}$ & & & & \\
\hline $\begin{array}{l}\text { Defensiveness > financial } \\
\text { performance }\end{array}$ & 0.080 & 0.654 & 0.513 & Rejected \\
\hline $\begin{array}{l}\text { Futuristic }>\text { financial } \\
\text { performance }\end{array}$ & 0.124 & 1.383 & 0.167 & Rejected \\
\hline $\begin{array}{l}\text { Analytic }>\text { financial } \\
\text { performance }\end{array}$ & 0.128 & 1.229 & 0.219 & Rejected \\
\hline $\begin{array}{l}\text { Aggressiveness > non- } \\
\text { financial performance }\end{array}$ & $0.198 * *$ & 2.864 & 0.004 & $\begin{array}{l}\text { Fail to } \\
\text { Reject }\end{array}$ \\
\hline $\begin{array}{l}\text { Proactiveness > non- } \\
\text { financial performance }\end{array}$ & & & & \\
\hline $\begin{array}{l}\text { Riskiness > non-financial } \\
\text { performance }\end{array}$ & $0.173^{* *}$ & 2.530 & 0.011 & $\begin{array}{r}\text { Fail to } \\
\text { reject }\end{array}$ \\
\hline $\begin{array}{l}\text { Defensiveness }>\text { non- } \\
\text { financial performance }\end{array}$ & 0.029 & 0.402 & 0.688 & Rejected \\
\hline $\begin{array}{l}\text { Futuristic > non-financial } \\
\text { performance }\end{array}$ & $0.255^{* *}$ & 3.211 & 0.001 & Rejected \\
\hline $\begin{array}{l}\text { Analytic > non-financial } \\
\text { performance }\end{array}$ & $0.283^{* *}$ & 3.863 & 0.000 & $\begin{array}{l}\text { Fail to } \\
\text { reject }\end{array}$ \\
\hline
\end{tabular}

Source: Field Survey (2018)

Discussion

The study sought to determine whether strategic orientation influences performance of star-rated hotels involved in the study or not. To 
achieve this, the study hypothesized that strategic orientation has no significant effect on performance of starrated hotels. All the items measuring strategic orientation and performance were put together respectively. The results of the study indicated that strategic orientation has a significant effect on performance compositely. This means that the hypothesis that strategic orientation has no significant effect on the performance of starrated hotels is, therefore, rejected.

The coefficient of determination, which is the $\mathrm{R}^{2}$, predicted 31.46 percent change in performance. Strategic orientation provides direction on the future of the organization. The findings indicate that how a firm chooses to interact with elements of the external environment, such as the customers, competitors and technology, affects the level of performance of the firm. As posited in the resource dependency theory, the longterm survival of a firm is dependent on its ability to link internal and external environment (Pfeffera \& Salanack, 1978). The findings, therefore, support the position of the theory, and posits that reliance on internal resources alone cannot achieve long-term survival and that an interaction between both internal and external environments is a key driver of performance. This was confirmed by the effect size, which recorded a large effect size. Further, the predictive relevance of the model also confirmed that strategic orientation predicts performance compositely. The finding is consistent with the findings of Gatignon and Xureb (1997), who also established a positive relationship between strategy and performance. Similarly, Day (1994) also established that strategic orientation may have direct implications for organizational performance.

The results also confirm the findings of Sin et al. (2005), who also established that strategic orientation affects the level of performance of hotels in Hong Kiong. Though the study area differs from that of Hong 
Kong, the study results do not differ and, therefore, affirm that strategic orientation affects performance. Similarly, Zhou and $\mathrm{Li}$ (2007) also found out that strategic orientation is a significant driver of superior performance in emerging economies. The study findings thus affirm this finding, considering Ghana as emerging economy on the African continent. The study finding is also consistent with that of Amirkahani and Keza (2015). The study finding, however, fails to confirm that of Jassmy and Bhaya (2016), who found insignificant relationship between strategic orientation and performance. The findings also validate the findings of the study of Han and Verma (2012), who recommended for replication of the study in other countries to either affirm or disprove the findings in that study. The finding of the current study, therefore, validates the findings of Han and Verna (2012) and indicate that the strategic orientation that a hotel adopts is a predictor of the level of performance of the hotel.
Further, the study analyzed the strategic orientation and financial performance to determine which of the strategic orientation type is a better predictor of financial performance. The study results indicated that none of the constructs significantly predicted financial performance of starrated hotels in Ghana. Aggressiveness, analytic, defensiveness and futuristic were all found not to be significant predictors of financial performance. The results, as presented in Figure 2, recorded a very low $R^{2}$ of 0.08 , thereby affirming the finding that strategic orientation does not significantly predict financial performance, contrary to the earlier findings that strategic orientation compositely predicts performance. The T-statistics for the four constructs were all below 1.96 and that explains the insignificant contribution of strategic orientation to financial performance. On the contrary, Han and Verma (2012) rather established that futuristic and defensive strategic orientation drove financial performance. 
The effect size was small and the predictive relevance was also weak. This clearly indicates that although strategic orientation compositely predicts performance, it rather does not contribute to predicting financial performance as the predictive relevance of the model was weak.

These findings could be explained by the nature of the business environment in which hoteliers work. The high cost of electricity and other utilities makes it difficult for hotels to pursue some of these strategic orientations with the hope of making financial gains. For example, being aggressive and cutting prices to increase financial performance is not sustainable in the long run. The cost of electricity and labour makes such an orientation unsustainable in the Ghanaian context. Further, the study established that strategic orientation rather drove nonfinancial performance indicators, such as increasing mutual trust, increasing the number of customers that visit the facility and the productivity of employees. This was confirmed in the $\mathrm{Q}^{2}$ results, which showed a moderate predictive relevance. Strategic orientation types, such as aggressiveness, analytic, futuristic and riskiness, were rather found to be significant predictors of non-financial performance. The finding is, however, consistent with that of Nzioka and Njuguma (2017), who also indicated that strategic orientation of firms is positively and significantly related to performance.

\section{Conclusions}

The implications of the study findings are of two-fold: first, to business and, second, to theory. Firstly, with respect to business, the findings imply that the strategic orientation that a business adopts in pursuit of its long-term goals influences the level of performance of the business. However, the key question that the study sought to answer is which of the strategic orientation types should be pursued to realize both financial and non-financial performance? The study findings indicate that strategic orientation should be 
used in pursuit of non-financial gains, such as building trust, increasing the number of customers that visit the hotels, and enhance employee productivity. The achievement of these non-financial performance goals would also reflect in financial gains to the hotels.

Secondly, with respect to theory, the study contributes to the resource dependency theory and posits that how a firm interacts with its external environment within the hotel industry of Ghana could only enhance non-financial gains, such as building trust, increasing the number of customers that visit a facility and increasing employee productivity. It, therefore, affirms the theory and explains that not only should firms rely on internal resources to achieve performance targets rather how a firm chooses to interact with its external environment could also enhance the performance of the firm.

\section{References}

Abong, G. O., Ndanyi, V. C. M., Asante, S. B., Osei-Asare, Y. B., \& Kaaya, A., Shibairo, S. I., Okoth, M. W., \& Lamuka, P.
O. (2016). A review of production, post-harvest handling and marketing of sweetpotatoes in Kenya and Uganda.

Acheampong, P. P., Nimo-Wiredu, A., Amengor, N. E., NsiahFrimpong, B., Haleegoah, J., Adu-Appiah, A., \& Adogoba, D. (2017). Root and Tuber Crops Technologies Adoption and Impact Study in Ghana: The Case of Improved Cassava Technologies. West Africa Agricultural Productivity Programme, Crops Research Institute and Savannah Agricultural Research Institute, Accra.

Aidoo, R. (2009). An analysis of yam consumption patterns in Ghanaian urban communities. Unpublished doctoral dissertation. Department of Agricultural Economics, Agribusiness and Extension, Faculty of Agriculture, Kwame Nkrumah University of Science and Technology, Kumasi Ghana.

Kuwornu, J. K. (2016). Smallholder maize farmers' 
food consumption Bech-Larsen, T., Grunert, K. G., and expenditures in Ghana: The mediating role of commercialization. AGRIS on-line Papers in Economics and Informatics, 8(665-201645097), 13-27. Poulsen, J. B. (2001). The Acceptance of Functional Foods in Denmark, Finland, and the United States. MAPP Working Paper No. 73. MAPP, Aarhus, Denmark.

Anokye, M., Tetteh, J. P., and Otoo, E. Blaylock, J., Smallwood, D., Kassel, (2014). Morphological K., Variyam, J., and Aldrich, characterization of some L. (1999). Economics, Food water yam (Dioscorea alata Choices, and Nutrition. Food L.) germplasm in Ghana. Policy, 24, 269-86.

Journal of Agricultural Bonilla, T. (2010). Analysis of Science and Technology, B, 4, consumer preferences toward 518-532.

Bakulumpagi, A. (2018). Use of $100 \%$ fruit juice packages and underutilized Elite Banana Cultivars in the production of Composite Tomato Ketchup (Doctoral dissertation).

Bateman, I. J., Carson, R. T., Day, B., Hanemann, W. M., Hanley, N., Hett, T., Jones-Lee, M., labels. A Master of Science thesis submitted to the Department of Agricultural Economics and Agribusiness, Louisiana State University and Agricultural and Mechanical College, Costa Rica.

Loomes, G., Mourato, S., Brillouet, J.-M., Treche, S., and Sealy, Ozdemiroglu, E., Pearce, L. (1981). Alterations in cell D.W., Sugden, R., and wall constituents of yams Swanson, S. (2003). Dioscorea dumetorum and Guidelines for the Use of Dioscorea rotundata with Stated Preference Techniques for the Valuation of maturation and storage Preferences for Non-Market Goods. Edward Elgar, Cheltenham. conditions in relation to postharvest hardening of $D$. dumetorum yam tubers. Journal of Food Science 46, 1954-1965. 
da Silva Dias, J. C. (2014). Guiding strategies for breeding vegetable cultivars. Agricultural Sciences, 5(1), 9. Idang, G. E. (2015). African culture and Fungo, R., Muyonga, J. H., Kabahenda, M., Okia, C. A., \& Snook, L. (2016). Factors influencing Lancaster, K. (1966). A New Approach consumption of nutrient rich forest foods in rural Cameroon. Appetite, 97, 176$-184$.

Fungo, R., Tieguhong, J. C., Muyonga, J. H., Odjo, S., Tchingsabe, O., \& Tchatat, M. (2018). Perceived nutrition benefits and socio-demographic factors affecting consumption of forest foods in eastern and southern Cameroon. African Crop Science Journal, 26(2), 203-217.

Ghana Statistical Service (2008). Ghana Living Standards Survey Round 5 (GLSS5); GSS, Accra, Ghana.

Goron, T. L., \& Raizada, M. N. (2015). Genetic diversity and genomic resources available McFadden, D. (1986). The Choice for the small millet crops to accelerate a New Green Revolution. Frontiers in plant science, $6,157$.

Hensher, D. A., Rose, J. M., and Greene, W. H. (2005).
Applied Choice Analysis: A Primer. Cambridge: Cambridge University Press. values. Phronimon, 16(2), 97111. to Consumer Theory. Journal of Political Economy, 74(2), 132-157.

Lancsar, E., and Louviere, J. (2008). Conducting discrete choice experiments to inform healthcare decision making: a user's

guide. Pharmacoeconomics, 26(8), 661-677.

Louviere, J. J., Hensher, D. A., Swait, J. D., \& Adamowicz, W. L. (2000). Stated Choice Methods: Analysis and Applications. Cambridge, UK: Cambridge University Press.

Luce, R. D. (1959). Individual Choice Behaviour: A Theoretical Analysis. Wiley, New York. Theory Approach to Market Research.

Marketing Science, 5(6), 275-297.

McFadden, D. (1974). Conditional logit analysis of qualitative choice behaviour. In P. 
Zarembka (ed.) Frontiers in Econometrics. NY: Academic Press. production. Journal of Experimental Botany, 63, 1075-1079.

McFadden, D., Train, K., and Tye, W. Mohanty, S. K., Balcombe, K., B. (1976). An Application of Diagnostic Tests for the Independence from Irrelevant Alternatives Property of the Multinomial Logit Model. Transportation Research Record, 637, 39-45. Bennett, R., Nocella, G., \& Fraser, I. (2019). Attribute Specific Impacts of Stated Non-Attendance in Choice Experiments. Journal of Agricultural Economics, 70(3), 686-704.

Marschak, J. (1960). Binary-Choice Nakashima, D. \& Roue, M. (2012). Constraints and Random Utility Indicators, in $\mathrm{K}$. Arrow

(Ed) Stanford Symposium on Mathematical Methods in the Social Sciences. Stanford University Press, Stanford. Mensah, C. (2005). Response of 'Pona' and 'Asana' cultivars of white yam, Dioscorea rotundata (Poir) to the minisett technique of yam propagation. M.Phil. Thesis, Department of Crop Science, Indigenous Knowledge, Peoples and Sustainable Practice, Social and Economic Dimensions of Global Environmental Change, 5, 314-324

Ndungu, S. K. (2013). Consumer Survey of Attitudes and Preferences Towards Organic Products in East Africa A report presented to International Federation of Organic Agriculture University of Cape Coast, Obidiegwu, J. E., \& Akpabio, E. M. Ghana.

Mayes, S., Massawe, F. J., Alderson, P. (2017). The geography of G., Roberts J. A., Azam-Ali, yam cultivation in southern S. N., and Hermann, M. Nigeria: Exploring its social (2012). The potential for underutilized crops to meanings and cultural functions. Journal of Ethnic Foods, 4(1), 28-35. improve security of food 
Okoffo, E. D., Denkyirah, E. K., Adu, D. T., \& Fosu-Mensah, B. Y. (2016). A double-hurdle model estimation of cocoa farmers' willingness to pay for crop insurance in Ghana. SpringerPlus, 5(1), 1-19.

Ouma, E. A. (2007). Economic Train, K. (2003). Discrete Choice Valuation of Phenotypic Cattle Trait Preferences in Trypanosomiasis Prevalent Production Systems of Eastern Africa: Implications for Sustainable Cattle Breeding Programs. PhD Thesis, Christian-Albrechts University of Kiel, Germany. Thurstone, L. (1927). A Law of Pearmain, D., Swanson, J., Kroes, E., and Bradley, M. (1991). Stated preference techniques: a guide to practice (2nd ed.). Yasuoka, Steer Davies Gleave and Hague Consulting Group.

Sato, H. (2006). A brief report on a large mountain-top community of Dioscorea praehensilis in the tropical rainforest of south-eastern Zulu, Cameroon. African Study Monographs, Supplement.33, 21-28.

Shiferaw, B., Smale, M., Braun, H. J., Duveiller, E., Reynolds, M., \& Muricho, G. (2013). Crops that feed the world 10. Past successes and future challenges to the role played by wheat in global food security. Food Security, 5(3), 291-317. Methods with Simulation (1st ed.). Cambridge University Press, UK.

Treche, S., and Guion, P. (1979). Etude des potentialities nutritionals de queues tubercles tropic au Cameroun. Agronomy Tropical 34, 127-131.

Comparative Judgement. Psychological Review, 34, 273-286.

H. (2009). Concentrated distribution of wild yam patches: Historical ecology and the subsistence of African rainforest hunter-gatherers. Human Ecology, 37(5), 577587.

M. (2019). Consumer preferences for common dry beans in Lusaka, Zambia (Doctoral dissertation, The University of Zambia). 